\title{
Mitteilung der Herausgeber - 85 Jahre Forschung im Ingenieurwesen
}

\author{
Thomas Lehnert
}

Online publiziert: 1. April 2015

(C) Springer-Verlag Berlin Heidelberg 2015

Editors-in-Chief: Torsten Bertram, Dortmund; Stefan Kabelac, Hannover; Karsten Stahl, München; Thorsten Schmidt, Dresden.

Publishing Editor: Thomas Lehnert, Berlin.

Vertreter des VDI: Dieter Westerkamp, Düsseldorf

„Forschung im Ingenieurwesen“ - „Engineering Research“ erscheint im Einvernehmen mit dem Verein Deutscher Ingenieure im 85. Jahr.

Seit dem ersten Heft (1930) bietet die Zeitschrift einen Überblick über aktuelle Forschungsarbeiten auf wegweisenden Gebieten der Ingenieurwissenschaften. Mit den Anfängen als Technische Mechanik und Thermodynamik (Band/ Vol. 1) entwickelte sich schnell der Bedarf nach interdisziplinärem Austausch.

Bereits Band/Vol. 2 erschien 1931 unter dem Titel Forschung auf dem Gebiete des Ingenieurwesens A. Der Vertreter der Herausgeber, Professor Dr.-Ing. A. Nägel, Vorsitzender des Wiss. Beirats des VDI, schrieb dazu 1931: „In den letzten Monaten des vergangenen Jahres hat sich der Verein deutscher Ingenieure mit einer Schrift ,Forschung tut not' an die breite Öffentlichkeit gewandt. ... Die Forschung lieferte nicht nur das wissenschaftliche Rüstzeug, dessen die Technik zu ihrem Fortschritt bedurfte, sie half auch, deutschem Ingenieurgeist in der Welt Geltung zu verschaffen und damit kulturelle und wirtschaftliche Fäden zwischen den Nationen zu knüpfen... Aus solchen Erwägungen betrachtet der Verein deutscher Ingenieure gerade in der Gegenwart die Unterstützung forscherischer Tätigkeit als eine seiner vornehmsten Aufgaben."

T. Lehnert $(\varangle)$

Berlin, Deutschland

E-Mail: Thomas.Lehnert@springer.com
Die Zeitschrift fördert seit 85 Jahren den interdisziplinären Austausch zwischen Arbeitsgebieten in Forschung und Entwicklung und erreicht heute Leser weit über die Grenzen deutschsprachiger Länder hinaus.

Mit der Auswertung durch Science Citation Index Expanded (SciSearch), Journal Citation Reports/Science Edition, SCOPUS, Chemical Abstracts Service (CAS), Google Scholar, EBSCO, Academic OneFile, CEABA-VtB, CSA Environmental Sciences, Current Contents/Engineering, Computing and Technology, EI-Compendex, Gale, INIS Atomindex, International Bibliography of Book Reviews (IBR), International Bibliography of Periodical Literature (IBZ), OCLC, SCImago, sowie Summon by ProQuest erfährt die Zeitschrift eine hervorragende Wahrnehmung in der weltweiten Wissenschaft.

Springer konnte bereits mit der Öffnung der Inhalte über SpringerLink die Basis schaffen für weltweite Sichtbarkeit und Verfügbarkeit. Heute erreicht jeder auf SpringerLink publizierte Beitrag gezielt die Hauptzielgruppen. Damit gewinnen Zeitschriften mit Überblickscharakter wie diese wieder an Bedeutung.

Springer und VDI nehmen diese Entwicklung zum Anlass um der bewährten Zusammenarbeit neue Impulse zu verleihen. Mit neuen Herausgebern wird eine fundierte Basis zur fachlichen Beurteilung hervorragender Forschungsergebnisse vor ihrer Publikation geschaffen. Springer dankt den Herausgebern für ihren Mut und Einsatz und wünscht ihnen eine glückliche Hand zur erfolgreichen Bewältigung der Aufgaben. Dem VDI dankt Springer für die Zusammenarbeit im Hinblick auf das Ziel der Veröffentlichung von herausragenden wissenschaftlichen Arbeiten zur Stärkung der deutschen Ingenieurwissenschaften und des Technikstandorts Deutschland.

Berlin, im März 2015 Thomas Lehnert, Springer-Verlag 


\section{Publisher's Editorial 2015 - 85 Jahre Forschung im Ingenieurwesen}

„Forschung im Ingenieurwesen“ - „Engineering Research“ is published in agreement with Verein Deutscher Ingenieure.

Since publication of the first issue (1930), the Journal provides an overview of current research in pioneering areas of engineering. With its beginnings as Technische Mechanik und Thermodynamik (Vol. 1) the growing readership developed the need for interdisciplinary exchange. Vol. 2 appeared in 1931 as Forschung auf dem Gebiete des Ingenieurwesens $A$. The representative of the VDI, Professor Dr.-Ing. A. Naegel, Chairman of the Scientific Advisory Board of the VDI, wrote in 1931: „In the last months of last year, the Association of German Engineers VdI published a paper ,In Need of Research/Forschung tut not ““ ... Research not only provided the scientific skills for progress in technology, along with worldwide reputation for German engineering spirits, as well as an ongoing cultural and economic exchange among nations... „This triggered considerations by the Association of German Engineers VdI to support research activities as one of its primary duties."

The journal promotes the interdisciplinary exchange between work areas in research and development for 85 years now. Today it has readers far beyond the borders of German-speaking countries. With the evaluation by the Science Citation Index Expanded (SciSearch), Journal Citation
Reports/Science Edition, SCOPUS, Chemical Abstracts Service (CAS), Google Scholar, EBSCO, Academic OneFile, CEABA-VtB, CSA Environmental Sciences, Current Contents/Engineering, Computing and Technology, EI Compendex, Gale, INIS atom index, International Bibliography of Book Reviews (IBR), International Bibliography of Periodical Literature (IBZ), OCLC, SCImago, Summon by ProQuest the papers published in the Journal are well acknowledged in global science. By opening of content to many researchers via SpringerLink Springer provided the basis for worldwide visibility and availability. Today, every paper published in the Journal receives straight acknowledgement by the main target groups too.

On this occasion Springer and VDI take the opportunity to develop the trusted cooperation with a new impetus. The new Editors-in-Chief are well respected researchers themselves, ensuring a solid basis for academic assessment and peer review of outstanding research prior to publication. Springer would like to thank the Editors for their courage and commitment and wishes them success. Springer appreciates the support by VDI in the light of the objective of the publication of outstanding scientific work to strengthen both the communication between German Engineering Research Communities and their international counterparts as well as the Technology Developments in Germany.

Berlin, March 2015 Thomas Lehnert, Springer-Verlag 